\title{
Memoir on Remains of the Anglo-Roman Age, at Weycock, in the Parish of Laurence Waltham , Berkshire; and on the Excavations there Made in 1847
}

Direction of the Hon. Richard C. Neville F.S.A.

To cite this article: Direction of the Hon. Richard C. Neville F.S.A. (1849) Memoir on Remains of the Anglo-Roman Age, at Weycock, in the Parish of Laurence Waltham , Berkshire; and on the Excavations there Made in 1847, Archaeological Journal, 6:1, 114-123, DOI: 10.1080/00665983.1849.10850726

To link to this article: http://dx.doi.org/10.1080/00665983.1849.10850726

曲 Published online: 10 Jul 2014.

Submit your article to this journal ¿

Џll Article views: 1

Q View related articles ¿ 
MEMOIR ON REMAINS OF THE ANGLO-ROMAN AGE, AT IVEYCOCK, IN THE PARISH OF LAURENCE WALTHAM, BERKSHIRE; AND ON THE EXCAVATIONS THERE MADE IN 1847, BY DIRECTION OF THE HON. RICHARD C. NEVILLE, F.S.A.

A REPORT of the foundations discovered at Weycock will be best introduced by a few remarks as to its locality, which, combined with a record of the antiquities brought to light in the neighbourhood, may afford some clue to the origin and date of the structure, supposed to have been a fort or tower, and perhaps point out the people to whom it should be ascribed. Waltham Saint Laurence is five miles south-west of Maidenhead, and ten miles west of Windsor ; it forms a portion of the Hundred of Wargrave, which was granted by Edward VI. to Sir Henry Nevill, from whom it descended with the Billingbeare estates to Lord Braybrooke, the present possessor.

The field called Weycock, in which Roman remains have been frequently discovered, beyond the memory of man, is situated near the south-west extremity of the parish of Laurence Waltham.

That this spot contained the foundations of some building had been matter of notoriety, ever since the time of Camden, who, speaking of Sunning, states, in his Britannia, vol. i. p. 170, "not far off stands Laurence Waltham, where the foundations of an old fort are to be seen, and Roman coins are often dug up."

Hearne, in the preface to his edition of "Leland's Itinerary," alluding to Roman remains in the parish of White Waltham, his native place, remarks, that "the broken tiles, scatter'd up and down the ground in no small quantity, are like those in Weycock, (in the parish of Laurence Waltham,) about a mile westward." Further, also, "Weycock was without doubt," speaking of supposed Roman works at other places,- "such a work (and perhaps was once in Antoninus) there having been, as there are now continually, great numbers of coyns plough'd up by the husbandmen to confirm it : and 'twas from this evidence that Mr. Camden has said, that 'twas a Roman fort." 1

1 Leland's Itin. by Hearne, vol. i., Pref., p. x. 
Again, in his "Letter on Antiquities between Windsor and Oxford," 2 appended to the fifth volume of his edition of "Leland's Itinerary," Hearne enlarges more particularly on the subject:- "Leaving Shottesbroke, about half a mile on this side you stopped at a village call'd Laurence Waltham, that formerly belonged to the Abbey of Hurley. Here you told me you were shew'd several coyns of the Lower Emperors, found in an adjacent field, which you took the more notice of, because Mr. Camden tells us that in that field was a Roman Fort, as he gather'd from the coyns frequently found by the husbandmen. I have been shew'd divers of these coyns, and I was once of opinion, that 'twas built about the time of Constantius the Younger, but I have since chang'd that opinion, and I now believe 'twas founded many years before. I have, amongst other coyns, seen one that was dug up here of Claudius Gothicus." Whence he argues, that "this Roman castle was in a flourishing condition after the year CcLxx., and perhaps it might continue so till very near the invasion of the Saxons. 'Tis not unlikely but that it had a great dependance upon Silchester in Hampshire, which is at no great distance from it, and had a very considerable command over this part of the island, being a very large place, \&c. But omitting this, which is nothing more than conjecture, 'tis certain, from the vast number of old bricks and other ruines, that this fort in the parish of Laurence Waltham was of considerable extent, and of no small strength. The field in which it stood is now call'd Weycock, which tho' in the first draught of this letter," (in 1708) "I thought it to be nothing but a corruption of the Saxon word Wig-stow, i.e., a place of incamping, or a fort, yet I have since that time alter'd my opinion, as I have noted in my Preface to the first volume of Mr. Leland's Itinerary." 3 The supposition of Hearne, that Weycock was occupied towards the time of Saxon invasion, would seem to be most probable, and indeed, judging from the character of the remains, the fortress may possibly have been occupied at that epoch, usually designated the "transition period." But whatever the precise date of the building, it certainly gave a name to the locality, that particular portion of common land covered by the foundations, being called, previously to its enclosure, "Castle Acre," an appellation the

2 Published first in the "Memoirs for the Curious," for Nov., 1708, and Jan. 1709 ; also separately in $1735,8 \mathrm{vo}$.

3 Leland's Itin., vol. v., p. 154. 
more remarkable, as it occurs in other parts of England, where ancient remains are to be met with, such as Castle Acre, in Norfolk. In reference to the signification of this term, especially with regard to the present instance, the following remarks, by Hearne, may not be considered out of place. They are extracted from his glossary appended to "Peter Langtoft's Chronicle," under the word " akres." 4

He observes that the word "akre" had formerly a more extended sense, denoting a field, according to its Saxon derivation (Acere, ager, campus) and not merely that small quantity of land, now termed an acre.

"From this extensive signification of the word in old time, I cannot but observe, that whereas in some places, where there have been undoubtedly Roman works, the common people, as well as others, make use of Castle Acre, to distinguish such a piece of ground where they have been, I think we ought not to restrain that term to our modern narrow acceptation of the word, but look upon it to be meant in the old sense, so as to denote an intire field. So whereas by Castle Acre in Weycock Field, in the parish of Laurence $\dot{W}$ altham, near Maidenhead in Berks, the country people commonly understand no more ground than what is now generally known by the term acre, I rather think that 'tis to be understood of the whole field, at least of a great many of our common acres, and that the building there was very large; a thing which the great number of antiquities found in the field proves very plainly: in reference to which I shall here transcribe what I have put down in one of my MSS. ${ }^{5}$ a few years since, when in my walk I lay at Hare-hatch, and the next day went through this field, as I have upon occasion done several times.- 'April 1, 1719. From Hare-hatch I walk'd to Shottesbrooke, and pass'd through a great field (in the parish of Laurence Waltham) called Weycock. One part of this field is call'd Castle Acre. There is a tradition, that there was a large castle there. Indeed there is no manner of doubt but in this field there was once a very considerable fort, and several buildings besides. The ground call'd Castle Acre is higher than the rest. Abundance of Roman money hath been found in this field of Weycock. I discovered in many places of it fragments of Roman bricks. I met with two or three workmen, with whom I talk'd about this

+ Vol. ii., p. 519.

5 Vol. lxx., p. 91. 
field, particularly about the coyns found in it. There was a youth with them, who told me that a great many little pieces of money had been plough'd up in this field, and a many pretty things (says he) besides. I ask'd him where any of them might be seen; he said at Mr. Nevill's of Billingbeare. I am apt to think that some of the pretty things he mention'd might be tessellæ of some Roman pavement. My great friend, Francis Cherry, Esq., had many coyns found in this field, one of which was a silver one of Amyntas, and this I have published in Leland's Itinerary." "6

Thus then, it appears, that while Castle Acre is applied solely to the portion of ground containing the remains, the name of Weycock comprehends the whole field, and as the former word is evidently derived from the foundations there deposited, we must next explain the meaning of the latter appellation. According to Hearne it may be traced to the Saxon "Wæg Coppe," the "road on the hills," which he considers a more probable derivation than his first conjecture, that it might be taken from "Wig-stow," a place of encampment or fort; the former certainly appears to be a more satisfactory interpretation of the term, and in accordance, as Hearne remarks, with the natural position of the site. ${ }^{7}$

A few additional particulars may be gleaned from the Berkshire collections, and answers to queries regarding the parochial history of that county, circulated by Mr. E. Rowe Mores, in 1737, and preserved in the fourth volume of the Bibliotheca Topographica. The following notes given in that valuable work may be cited, in addition to what has already been stated. "Waltham St. Laurence.-There was a considerable Roman fort in the neighbourhood of this place. It stood in a field called Weycock Highrood. This is a very spacious common field, appearing to contain about 150 acres. It is entirely open and free from trees. The fortress was built on the highest part of it, where there is a pretty large piece of very level ground, and a very delightful spot, commanding a distant view of Windsor Castle, and a large extent of country towards the east, south and southwest. The site of the fortress goes at this day by the name

${ }^{6}$ See two representations of this coin dug up at Weycock, Leland's Itin., vol. v., p. 157 , edit. 1769 .

"See Hearne's "Letter," as first given vol. VI. in the Memoirs, above cited ; and his corrections in Leland's Itin., vol. i., p. xii.; vol. v., p. 1.54 . 
of Castle-acre. I was told by several of the labourers, that every year, when they plough this spot, it is usual to turn up several pieces of old coin, chiefly copper, and of that mixed metal known by the name of Corinthian brass. Some pieces of gold have likewise been found. One of these honest countrymen told me that some pieces had a great deal of reading upon them. It is probable, therefore, that medals were deposited here as well as coin. A gold chain was likewise found, which the discoverer sold to a blacksmith of Reading. Many of the coins were collected for the present Mr. Vansittart's father, and for another gentleman, a lover of virtú, whose name I have forgot. These ploughmen generally give them to their children for playthings. They report that the highway to London formerly lay across this field, whence probably the name of High-rood, ${ }^{8}$ or Highroad."9

All these facts, combined with the assurance that these interesting remains were still in statu quo underground, induced me to investigate them during the months of May and June, 1847. The building occupied nearly a month in excavation, by two labourers, and when completely cleared, there was exposed to view a perfect octagon, enclosing another smaller, and of the same shape. My kind friend, Mr. Buckler, inspected the whoin, aind has been so good as to furnish me with remarks upon it, and the dimensions, as well as a ground-plan from his careful pencil: I am fortunate in being able to subjoin them, on so good an architectural authority. ${ }^{1}$ (See the accompanying plan and sections.)

Mr. Buckler observes, "It does not appear, from what I have found, that the walls were bonded with brick-work." 2 He gives the following dimensions:- "Height of walls, 8 feet; thickness, 3 feet 6 inches; distance apart, 10 feet 4 inches; diameter of inner octagon, including thickness of walls, 35 feet 11 inches; extreme diameter, 63 feet

9 Ashmole, also, makes Weycock signify the High-road, vol. ii., p. 431 .

9 Biblioth. 'Topogr. Brit, vol, iv., p. 135.

1 The Society is indebted to the lindness of Lord Braybrooke for the accompanying illustrations, representing the ground-plan, with a section of the entire remains, as also of a portion of the foundation walls, showing their construction. The Committee desire to express their thanlis to the noble possessor of this ancient site for the liberality which has thus enabled them to lay before the members of the Institute these memorials of a very singular structure.-Ev.

2 The two courses, which in the annexed woodeut have the appearance of wall-tiles or bonding-bricks at the outer face of the work, were formed, as it is stated, of thin slabs of stnne. 
ROMAN ANTIQUITIES IN BERJSHIRF.

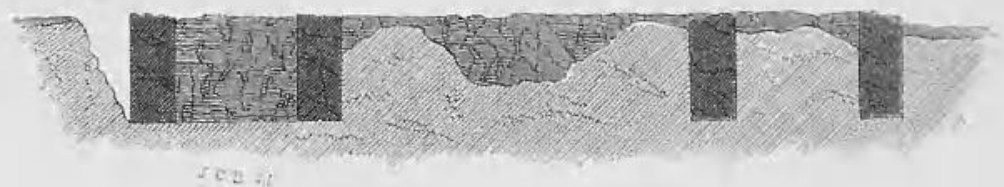

$\cos ;$

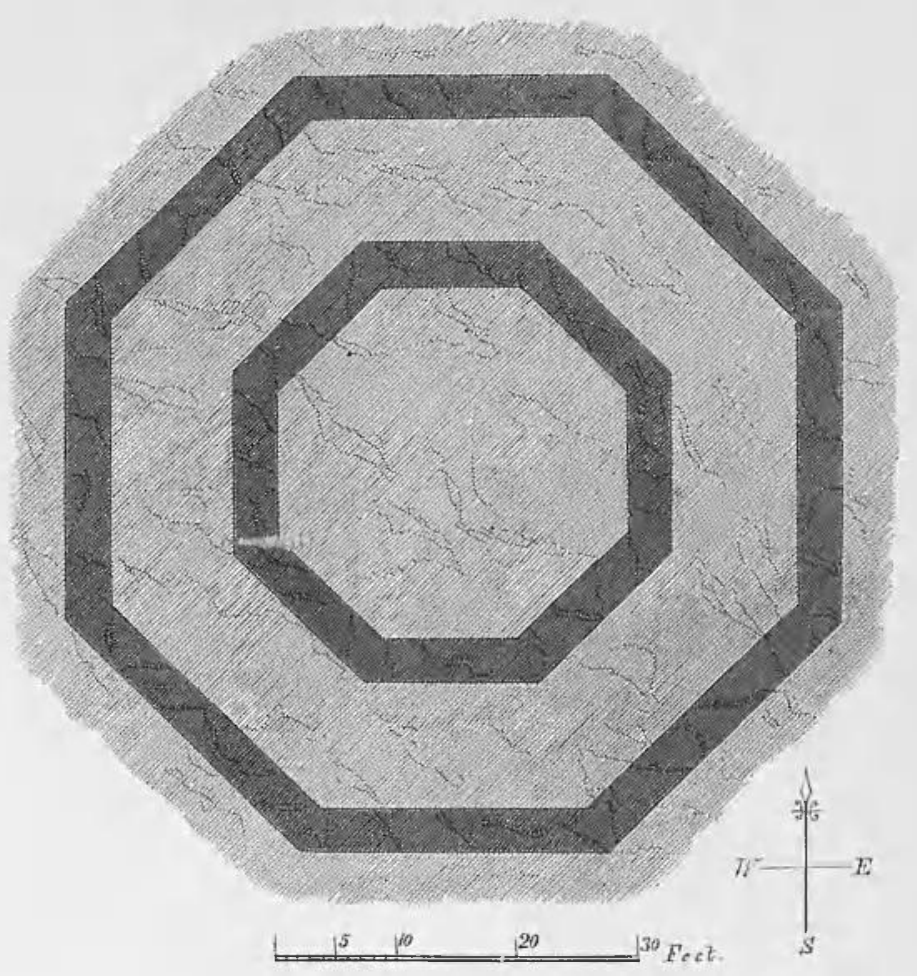

Octagonal Building, excavated by the Elon Richard Neville, in the Castle Acre, Weycock, May, 1817. 


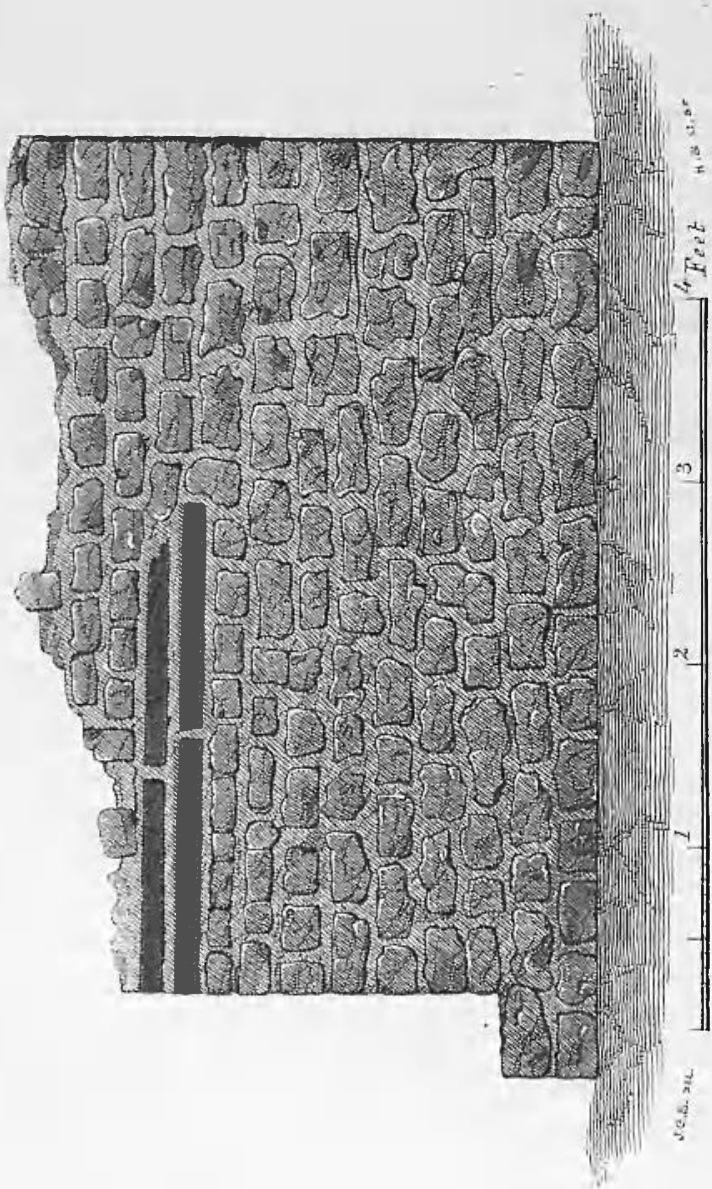

0
0
0
0
0
0
0
0
0
0
0
0
01

s

$\$$

丞

성

- B

巻

:

空

沓

焉

8

नี

$B$

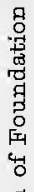

명 
7 inches; half a mile north-west of the church of Waltham St. Laurence. The walls have no extra breadth for foundations; soil, sand and loam; walls, 10 inches below the surface; ground in this direction, north-west, ascends gradually from the village; view from the ruins, towards the south, open and extensive, walls composed of flint not sorted, and laid in regular courses, as at Hadstock, but heaped together promiscuously, with a considerable quantity of mortar ; these are the foundation walls of the building, and were always deeply buried in the ground. Many fragments of Roman brick have been dug up during the operations. Flanged bricks among the number."

In addition to these summary remarks by Mr. Buckler, little can be said in regard to the construction of the vestiges of this building; it only remains therefore to add a list of the various articles discovered from time to time in their immediate neighbourhood.

Like all similar spots, this site appears to have abounded in coins, bricks, tiles, and other signs of Roman habitation, but of these scarcely any record is now attainable, and to the great number of relics carried away at intervals, previous to the investigation, must be attributed the extreme paucity of curiosities produced on that occasion.

Thus, of coins but three or four of Constantine were elicited, and not more than eight or ten fragments of pottery, though remains of amphore and culinary vessels were amongst the articles previously alluded to, as removed from this spot. Pieces of tile and brick were found in abundance, and the nature of the mortar used in the construction of the edifice yielded the most conclusive evidence as to its original builders. The Rev. Edwin Parker has most kindly furnished me with all the information that could be collected with regard to Weycock and the reliquix discovered there at various times, as well as an account subjoined of skeletons exhumed some years since: he has also presented to my museum every thing (whether coins or other antiques) that could be obtained in the neighbourhood, as having once belonged to Weycock. They include a silver denarius of Honorius: Rev., Rome standing; Leg., VICTORIA ROMANORUM. A denarius of the Antonia Family: Obv., a Galley; Rev., an Eagle between two Standards; Leg., LEGio viI. A third brass coin of Carausius: Obv., Three heads (Carausius, 
Maximian, and Diocletian); Leg., CARAVSIUS ET FRATRES SUI; Rev., Peace, to R., standing with ölive branch and hasta pura; Leg., PAX AVGGG. In the field, S. P. and C. in the exergue. ${ }^{3}$

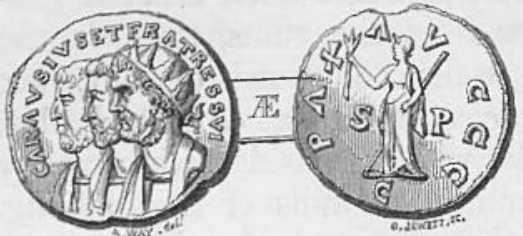

Coin of Carausius found at Weycock.

To these may be added many others in brass, presenting nothing worthy of mention, and consisting chiefly of coins of the Constantine family, Claudius Gothicus, Tetricus ; many with the Rev., Urbs Roma, and a second brass of Nero; two or three of Faustina Senior, and a Julia Domna. In addition to these, Mr. Parker mentions having seen, in the course of his residence in the parish, "fair impressions of Domitian, Antoninus, Verus, Aurelianus, and Maxentius," and that he has "handled hundreds of brass and copper coins of a large size, of which the impressions were entirely defaced." One coin, however, brought to light during my investigation, is sufficiently remarkable to require a particular description, and may assist in establishing a date for the occupation of the tower; this is a base silver Sceatta, lying amongst the foundations, and unfortu-

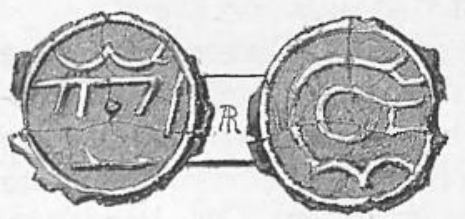

Sceatta found at Weycock, Berks. nately shattered by a blow from a pick, but the surface not otherwise injured. Mr. Birch, of the British Museum, to whom it has been submitted, remarks: "This specimen is of value in confirming many in our collection of the transition period, viz., the time between the departure of the Romans and succession of the Saxons." It has no lettering, but simply a device of two semi-lunes and lines, with peculiar curved lines on the other side, as shown in the annexed wood-cut.

Doubtless, many other and equally valuable coins might be traced, as formerly buried here, which are now deposited in a hoard almost as unfathomable, the depths of private museums, and some sold, it has been ascertained, to London dealers. A small bronze female head, ploughed up in the

${ }^{3}$ A representation of this interesting coin has been given, from a specimen in the British Museum, in the "Monumenta
Historica Britannica," recently published, pl. $x$., but the radiation usually seen on coins of Carausius is not expressed. 
Castle Acre, is in my possession, the hair carefully designed ; it is hollow, $1 \frac{1}{2}$ inch in height, and has been supposed to have been used as a stilyard weight. (See cut. Size of orig.)

But the most important discovery recently made at this spot, is thus described by Mr. Parker : "In the spring of 1837 , the excavators engaged in making a deep cutting for the Great Western Railway, when they had reached some low ground Bronze Head found at Weyrocks. on the east side of Weycock Field, came

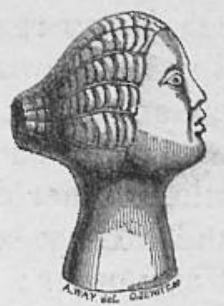
suddenly upon upwards of thirty human skeletons, and continued to find them through the distance of an acre of land. These I carefully examined, to see if broken limbs, skulls, or anything indicative of their having been slain in battle, could be detected; but in no instance was anything of the sort apparent. The bones were a few inches only below the surface, resting on the solid chalk, which had never been disturbed, and the bodies seemed to be laid in something like order, the limbs stretched out straight, and invariably in the same direction, following nearly the line of the excavation east and west. Most of the skulls had the teeth entire, and firmly imbedded in their sockets. A large number were exhibited to me, as, with a view of not losing the chance of any curiosity, I encouraged the workmen with half-crowns to bring me their treasures; but, as from this numerous deposit of skeletons, my yard began to assume the appearance of a charnel-house, and the plan grew expensive, our intercourse gradually ceased, and the bones were consigned to the churchyard. No doubt this was the place of sepulture attached to the castle, particularly as the tower (since discovered) was in close proximity to it. There was also a tradition that a chapel formerly existed on this spot, and that it was known as a burial-place. Further to the south, the labourers broke into a line of old wells, thereby corroborating Ashmole's statement (Hist. of Ber.tss, vol. I.), 'that there was once a village near Weycock.' They were regularly steened with flint to the depth of ten feet; they measured about four feet in diameter at the mouth : no ancient objects were found in them. A leaden coffin was found near the wells, which they broke up, and sold the metal. The coffin was said to have contained a coin, of which all trace was 
lost, and a brick, on which, probably, the head of the corpse rested (?). These facts cannot, however, be vouched for, as, much to my regret, I missed seeing the coffin. The railroad did not otherwise prove so rich in its results, as might have been expected; indeed, its direction lay too much south of Weycock for such to be the case. On a spot nearer to the castle, another deposit, to the number of forty skeletons, was found. These seemed to have been thrown into a hole without any order; probably they were the remains of persons killed in some of the numerous skirmishes which took place in the neighbourhood with Prince Rupert and the Cavaliers. They lay about three feet beneath the surface, in the chalk."

With regard to the Roman line of wells, might they not have been, in reality, a number of the circular pits or rubbishholes usually so abundant in the vicinity of Roman dwellings or stations, as at Ewell in Surrey, Chesterford, \&c., and which have, of late, afforded much subject for speculation to the curious, in comparing the contents of such places of deposit in different localities. At all events, whatever opinion may be held on the precise date, and minor points relating to Weycock or Castle Acre, sufficient evidence certainly exists that the building erected on that site was of Roman origin, and continued to be occupied by the founders and their successors for many generations.

\section{R. C. NEVILLE.}

In connexion with the curious remains described by Mr. Neville, it is scarcely necessary to remind our readers of the octagonal Pharos, at Dover, attributed to the Roman period, and the remarkable monument, known as the Turris magna, at Nismes, likewise of octagonal form, but placed upon a very massive six-sided basement. Several other octagonal towers exist in France, such as that of Montbran, near Montignon, in Brittany. Montfaucon speaks of these Gaulish buildings as of high antiquity, observing that some were constructed as early as the times of Caligula, and he supposes the octagonal form to have been in accordance with a fashion prevalent in Gaul. (Ant. Expl., tome iv., Supp., pp. 130, 145.) We are not aware that any other multangular detached structure of the Roman period has been noticed in England. The foundations of an octagonal building were discovered, in 1818, by Sir William Hicks, Bart., at Great Witcombe, Gloucestershire, forming a chamber connected with the adjacent buildings; the dimensions were considerably smaller than those of the foundations excavated by Mr. Neville, the greatest diameter of the octagon being about 26 feet 6 inches, and the thickness of the walls rather more than 2 feet. See a Memoir by S. Lysons, "Archaeologia," vol. xix., p. 178.

The Rev. E. Parker. Vicar of Waltham, observes, in a subsequent communication regarding Weycock, that the "Castle Acre" appears to include as nearly as possible the portion of land formerly covered by buildings, as indicated by the appearance of the crops, in bad seasons, clearly showing the proximity of foundations beneath. The occupiers of the site have at various times torn up foundations, 
cemented so strongly as to destroy all ordinary tools; and all the remains thus discovered tend to corroborate local tradition that these buildings were raised by the Romans. Mr. Parker reports that he has seen thousands of Roman coins found there, but two only which seemed Flemish. The foundations of the tower have been broken up, as far as practicable, and the excavation filled in: this building Mr. Parker considers to have stood on the southern side of the work, and to have been used for the purpose of observation. It must have commanded, if the structure were of considerable elevation, a great extent of country, as far as Cæsar's camp and other distant stations. An ancient way passed near it, leading, probably, from London through Coln Brook, Feens in White Waltham, where Roman remains have been found, and towards Reading by Streetly. On the north side of the octagonal building appeared a break in the foundation wall, possibly where the access to the staircase from the castle had been formed.

DESCRIPTION OF AN ANCIENT TUMULAR CEMETERY, PROBABLY OF THE ANGLO-SAXON PERIOD, AT LAMEL-HILL, NEAR YORK, BY JOHN THURNAM, M.D.

\section{(Continued from page 39.)}

The sepulchral mound now described is of a very remarkable character, and does not, so far as I am aware, correspond with any of the numerous tumuli or other ancient cemeteries which have hitherto been examined. It differs from the ordinary tumuli of this country, of whatever period or people, in respect of the great number of persons who have been interred in it. It has, indeed, been a cemetery rather than a barrow, and we may perhaps properly speak of it as a tumular cemetery. Some may be disposed to question whether it had originally a tumular character at all. The level, however, at which the undisturbed skeletons were found, is raised about three feet above the surrounding fields; and, from the greater slope of the ground in that direction, the skeletons on the south side have an elevation of seven or eight feet. The presence of lime or other calcareous matter amongst the clay, gravel, and stones, below the entire skeletons, appears also to indicate that the base of the mound is artificial, and that the tumulus has not been formed merely by the removal of the surface of the surrounding fields and garden. Down to a very recent period, however, gravel has been obtained from these fields, and it is very possible that part of the existing elevation of Lamel-hill may be due to the abstraction of gravel and subsequent levelling round the base of the mound. Whether there were not originally two or more distinct tiers of interments, of which all but the lowest have 